\title{
Providing for the Safety of the Participants of the Criminal Court Proceedings - The Subject of Cconcern of Russian Legislator, Government, Scientists and Practicians
}

Galina Yakovlevna Borisevich

Perm State University, pps64@mail.ru

Follow this and additional works at: https://commons.erau.edu/jdfsl

Part of the Criminal Procedure Commons

\section{Recommended Citation}

Borisevich, Galina Yakovlevna (2017) "Providing for the Safety of the Participants of the Criminal Court Proceedings - The Subject of Cconcern of Russian Legislator, Government, Scientists and Practicians," Journal of Digital Forensics, Security and Law: Vol. 12 : No. 3 , Article 11.

DOI: https://doi.org/10.15394/jdfsl.2017.1494

Available at: https://commons.erau.edu/jdfsl/vol12/iss3/11

This Article is brought to you for free and open access by the Journals at Scholarly Commons. It has been accepted for inclusion in Journal of Digital Forensics, Security and Law by an authorized administrator of Scholarly Commons. For more information, please contact commons@erau.edu.

(c)ADFSL 


\title{
PROVDING FOR THE SAFETY OF THE PARTICIPANTS OF THE CRIMINAL COURT PROCEEDINGS - THE SUBJECT OF CONCERN OF RUSSIAN LEGISLATOR, GOVERNMENT, SCIENTISTS AND PRACTICIANS
}

\author{
Galina Borisevich \\ Perm State University \\ Perm, Russia \\ kafedra-upik-pgniu@yandex.ru
}

\begin{abstract}
For many decades, the problems of the post-criminal impact onto the witnesses, complainants, other participants of the criminal procedures in Russian Federation has no solution. Criminal procedural Codes of 1922, 1923, 1960 did not mentioned them. Gradually, these problems have gained a widespread importance and interpretation. The fear of reprisal from the criminals, their close neighbourhood, the possibility to reprise led to the witnesses' and the complainants' refusal to testify or to changing the testimonies. All that negatively influenced substantiating the circumstances of the criminal cases. The absence of the safety measures in the legislation of the USSR and Russia did not add to strengthening of the legitimacy.
\end{abstract}

Keywords: criminal procedures, post-criminal impact, protection of the complainants, safety measures

\section{INTRODUCTION}

Even after the Constitution of 1993 was adopted, the criminal procedural legislation (Criminal Procedural Code of 1960) lagged behind the norms fixed it.

Gradually, the legal base of the safety measures application started to be developed in the state. One of the most important steps of Russia in developing the Conception of the Court Reform started on October 24, 1991, was adopting of Federal Law dd April 20, 1995 \# 45-FZ "About the State Protection of the Judges and Officials of the Law Enforcement and Control Bodies".
In connection with Russia's entering in 1996 the Council of Europe and its ratification in 1998 of the European Convention of Human Rights dd November 4, 1950, Russia joined the European system of the person's rights protection, and for this, Russia undertook a commitment to bring its national legislation to compliance with the European international norms, and also accepted the jurisdiction of the European Court of Human Rights. These circumstances significantly influenced the contents of the Russian Federation Criminal Procedural Code introduced in 2001. 
The unquestionable advantage of the RF Criminal Procedural Code of 2001 is the fixation part 3 of Article 11 in it: "should there be enough information that a complainant, a witness, or other participants of the criminal procedures or their relatives faced a lifethreatening, use-of-force-threatening, threatening of damaging or destroying their property, or other risky illegal actions, - the court, the prosecutor, the head of the investigation body, the investigator, the agency of inquiry, the head of the agency of inquiry, the head of the inquiry department and the inquiry officer, within the limits of their authority, use the safety measures for the persons listed above as defined by Articles 166 part 9, 186 part 2, 193 part 8, 241 item 4 part 2 и 278 part 5 of the Code, and other safety measures stipulated by the legislation of the Russian Federation".

\section{ANALYSIS OF RUSSIAN LEGISLATION}

On August 20, 2004, Federal Law \# 1119-FZ «About the State Protection of the Complainants, Witnesses and Other Participants of the Criminal Court Procedures» was adopted.

In respect of the protected person, one of the following safety measures or several of them together, can be used: 1) personal bodyguard, guardianship of the house and the property; 2) issuing special means of individual protection, means of communication and alert; 3) providing for the confidentiality of the data about the protected person; 4) moving to other place of living; 5) changing the documents; 6) changing of the appearance; 7) changing the place of work (job) or place or study; 8) temporary moving to a safety place and other safety measures provided by Federal Laws dd April 20, 1995 \#45-FZ and dd August 20, 2004, \#1119-FZ.
The safety measures can be applied to the judges, officials of the law-enforcement and control bodies; participants of the criminal case: the suspect, the accused, their authorised representatives, defenders, the witness, the complainant, the expert, the civil complainant, the civil defendant, the specialist, the translator, the witnesses to the search; their close relatives and people important for them.

The subjects of application of the safety measures are the court, the prosecutor, the head of the investigation authority, the investigator, the agency of inquiry, the head of the agency of inquiry, head of the inquiry department and the inquiry officer (Part 3 of Article 11 of the RF Criminal Procedural Code).

The bodies that perform the execution of the state protection measures are - Ministry of Internal Affairs of the Russian Federation (MIA); Federal Security Service (FSS); Federal Service for the Execution of Sentences (FSES); Ministry of Defence; Federal Customs Service (FCS): Ministry of Public Health and Social Development; Federal Medico-Biological Agency. The Ministry of Internal Affairs of the Russian Federation coordinates the activities of the listed bodies.

For the purpose of the effective application of federal laws on safety, the Russian Government introduced several normative acts. The adoption of a number of the regulations was of a great importance: dd October 27, 2006 "About Approval of the Rules of the Application of Specific Safety Measures for the Complainants, Witnesses and other Participants of a Criminal Case"; dd November 11, 2006 \#664 "About Approval of the Rules of Paying One-time Compensation for the Complainants, Witnesses and other Participants of the Criminal Proceedings, Having Received a Decision of the State Protection in the Stipulated Order"; dd March 3, 2007, \#134 "About the Approval of the 
Rules of Protecting the Information about Performing the State Protection of the Complainants, Witnesses and other Participants of the criminal Proceedings"; dd October 1, 2009, \#792 "About Approval of State Program "Providing safety for Complainants, Witnesses and Other Participants of the Criminal Proceedings in 2009-2013".

Within the framework of this program, all the system of the state protection was activated. Governmental Regulation \# 898 dd September 5, 2014 introduced State Program "Providing safety for Complainants, Witnesses and Other Participants of the Criminal Proceedings in 2014-2018" which is now being exercised in Russia.

It should be also mentioned that in accordance with Federal law dd April 5, 2010, \#45 "About Introducing Changes into Article 10 of Federal Law "About the State Protection of the Complainants, Witnesses and Other Participants of the Criminal Proceedings", the Government of the Russian Federation has the authority to define the order of providing the protected persons with the accommodation for moving. On September 21, 2012, for fulfilling RF Government order dd April 23, 2010, \# SIP4-2641, RF Government Regulation \# 953 was issued, that approved "The Rules of Exercising the Safety Measures in Moving the Protected Person to Another Place of Living as Practised for the Complainants, Witnesses and Other Participants of the Criminal Proceedings".

In Russia, a number of the departmental acts was introduced.

Thus, order \#281 dd March 21, 2007 by the Ministry of Internal Affairs agreed on the Administrative Procedure of the Russian MIA on performing the state function of protecting the judges, the officials of the law-enforcement and control bodies, providing safety for the participants of the criminal court process and their families.

The activity of the internal affairs bodies on treating the threatening messages is regulated by the "Instruction on the Order of Accepting, Registration and Treating the Complains, Messages and other Incident Information in the Internal Affairs Bodies" (Approved by the RF MIA order dd May 4, 2010, \#333).

For last $15-20$ years, the criminality in Russia has grown. And so the number of people with such a pre-trial restriction measure as taking into custody, has increased (Kulikov, V. 2016). The types of the post-criminal pressure onto the judges, the officials of the law enforcement and control bodies, participants of the criminal procedure, are becoming crueler, properly planned, more sophisticated. This is why the problem of the state protection of the persons mentioned above is still vital. One can say that the legislator in Russia is constantly improving the norms regulating the application of the measures of the state protection. So, Federal Law dd December 28, 2013, \#432-FZ changed several articles of the RF Criminal Procedural Code.

Article 227 was enlarged with new Part 31. "Should the criminal case be accompanied with a resolution of keeping in secrecy the information about any participant of a criminal procedure, the judge takes measures that exclude any possibility for any other participant of the criminal case to study this regulation".

Article 281 of the Criminal Procedural Code, dedicated to the announcing the testimony of the complainant and the witness, was changed with newly introduced Part 6 . "The announcement of the testimony of a juvenile complainant or witness, which was earlier received during the preliminary 
investigation or court hearing, as well as the demonstration of negatives, photos and slides made during the interrogation, replaying of the audio and video records, films of interrogation, is performed with no juvenile complainant or witness present, with no interrogation". At the request of the parties or at the court's initiative, a reasoned decision about the repeat questioning of the juvenile complainant of witness can be taken.".

Article 303 was amended with part 4 "Should the information about the personality of the complainant, the witness or other participant of the criminal procedure was secret in the court, the court, when announcing the sentence, refers to the nicknames of these people (pointing this fact out)".

Part 2-1 was added to Article 313 "Should the convict be protected by the state measures, the court makes a resolution or a regulation about the cancellation of these measures or about the continuation of their application".

What's more. Federal law dd July 21, 2014 \#251-FZ introduces part 6-1 into Article 241 of the Criminal Procedural Code "The accused participated in the court hearing personally. In exceptional cases, for the purpose of providing safety for the participants of the criminal procedures, when hearing cases on crimes as per Articles 205-206, 208, part 4, Article 211, part 1, Article 212, Articles 275, 276, 279 and 281 of the RF Criminal Code, in accordance with the request of any of the parties, the court is entitled to take the decision about the participation of the arrested accused via the video-conference means". In such situations, the accused can be granted with a last plea via the video-conference means (Article 293 of the Criminal Procedural Code).

Federal Law dd December 30, 2015 \#440FZ, has also introduced changes into some of the articles of the Criminal Procedural Code. I.e., the wording of Part 1-1 of Article 144 was changed "...The participants of checking the report on crime can be warned about the nondisclosure of the information of the pre-trial investigation in the order defined by Article 161 of the present Code. If necessary, the safety of the participant of the pre-trial investigation is provided in accordance with the order settled in Part 9 of Article 166 of this Code, including the situation of receiving a report on crime".

An important specification was added to Part 9 of Article 166 "Should there be a necessity to provide for the safety of the of the complainant, his representative, the witness, their close relatives, other relatives and people important for them, the investigator has the right not to mention any information about their personalities in the protocol of the investigation action where the complainant, his representative, the witness participate. In this case, the investigator, with consent of the head of the investigation body carries out a regulation in which the reasons of taking the decision of keeping this information in secret and the nickname of the investigation act participant are given, together with the sample of his signature which is to be used in the protocols of the investigation activities with his participation. The regulation is placed into an envelope which is sealed after that, attached to the criminal case files, and is kept there in conditions that exclude the opportunity for any criminal case participant to see it ... Keeping of the regulation in the conditions of secrecy is an important guarantee of providing safety of the process participant.

So, we need to make a reasoned conclusion that in the Russian state, there is a fairly sound legislative basis for helping the participants of the criminal proceedings, their relatives and people dear to them in the form of the measures of the state protection from the post-criminal pressure. Given the fact that the corruption and the organized crime are 
gaining a bigger scale, and most different forms of their manifestation, the legal basis of the analysed institution is being improved at present by the legislator and is going to get further development.

In Russia, the Public Prosecution Office controls how the listed laws are followed and enforced. For example, the General Procuracy of the Russian Federation checked the execution of the RF legislation on the state protection of the complainants, witnesses and other participants of the criminal procedures in the preliminary investigation bodies in for the period since 2006 till the first half of 2008 in 28 constituent territories of our state (Timoshenko, A. 2011).

With this, we need to agree that there are a number of problems in practising the institution of safety provision in Russia both of theoretical and of practical meaning. The legislation and the practice of its application need to be improved. The studying of these problems is the subject if the researches by the scientists and practicians.

In juridical community, a question of the reasons for the state protective measures application is being discussed.

In accordance with Part 3 of Article 11 of the RF Criminal Procedural Code, the safety measures are arranged for the protected persons in case there is capable data about lifethreatening, use-of-force-threatening, threatening of damaging or destroying their property, or other risky illegal actions. I.e., the reason for using the safety measures is the data (information, knowledge) about a real threat of committing a crime in regard to the protected persons in connection with their participation in the criminal proceedings. The data should be considered sound by the body that takes the decision about performing the state protection. The officials busy with the operative search, should already during the protection process study the circle of the threat-carriers and isolate the protected person from the possible contacts with them. It is important to avoid a risk for the protected person by any means. During these actions, it is already possible to understand the realness of the threat and evaluate the efficiency and the practicability of the efforts made (Ramazanov, I. 2012). A. Timoshenko reasonably notices that a real risk for the protected can appear much earlier than the first threat arrives. It can be supposed a priori, due to the specific character of the crime committed (for example, if we speak about bringing the members of an organized criminal group or gang to a criminal responsibility, after that group or gang killed dozens of people) (Timishenko, A. 2009).

Having researched this issue, A. Timoshenko refers to the practise of the European Court, which agrees that the reason for imposing secrecy onto the data about some of the participants of the criminal proceedings can be not only fact of a threat received by the person protected but also the conditions of committing the crime, other circumstances discovered in the criminal investigation that directly emphasizes the necessity to hide the information about the crime. It appears that in the law enforcement practice of Russia, there should be a unified approach to understanding and treatment of this issue, and this needs to be reflected in the legislation.

The scientists of Russia note that the interaction of the investigators and the officials of the state protection divisions in providing the safety of the participants of the criminal procedures should be improved (Samoroka, V.\& Beketov, M. 2012). V. Samoroka and M. Beketov developed sound recommendations that the investigator should most fully inform the officials of the state protection divisions about the personal data and the place of location of the protected person; about the list 
of documents attached to the regulation about safety measures application, about the forms of the active interaction of the investigator who manages the criminal case or the threat claim (threat report), and the divisions of the state protection. The realization of these recommendations in the law enforcement practice should lead to positive results.

Among all the safety measures stipulated by the legislation, the most widespread ones in the Russian law-enforcement practice are temporary relocation of the protected persons to a safe place; imposing secrecy on the information about the person, personal bodyguar. So, there is a problem with the application of other measures of the state protection defined by the law.

It is a pity, Russian law-enforcement authorities and courts lack or do not have special rooms for organizing the interrogation of a person with the conditions excluding his visual monitoring and having equipment for changing the voice (Kryukova, N. 2012).

In juridical literature, the problem is not concealed that dishonest officials abuse the procedural discretion, i.e. groundlessly impose secrecy onto the information about the personalities of the witnesses and the complainants. There are cases in practice, when, in the conditions of no risk for the complainant or the witness, they are given nicknames, and this contradicts the requirements of the law. In connection with that, the interrogation of the complainant or the witness in the conditions of the nonobviousness, gives the accused the defense an opportunity to demonstrate definite doubts in the admissibility of such testimony. Having received the anonymity, the questioned person due to the personal hostile feelings towards the accused, can demonize him.

In Russian juridical community, there is an acknowledged necessity of the psychological skills and knowledge for the officials working at the divisions of the of the state protection or involving professional psychologists for working with the protected persons. However, this necessity is not properly satisfied, although the corresponding work is being done in Russia. The specialists reasonably notice that in reality there are difficulties with finding contact with the protected person, in making him understand the importance of his participation in the court process, in making him trust the measures taken by the officials of the authorized bodies for his safety. The protected persons suffer from the difficulties as his usual way of life is changed, because he is limited in his actions, in his obligations fulfilment and in his civil rights realization. With this, the situation gets more complicated because of the fact that a significant number of the protected persons have already got social, personal and psychological disorder, some of them have an anti-social way of life or come from criminal environment (Ivanov, I. 2012).

It is a pity that often the protected persons do not observe their obligations prescribed by the law (do not inform the state protection division about every case of a threat or illegal actions against them; disclose the information about the arranged safety measures with no permission of the state protection division; do not inform about their travel schemes etc.). Such a behaviour of the protected persons makes the work of the state divisions much more complicated. Meanwhile, the safety measures are organized based on a written claim of the protected person or with his consent, and in respect of the juveniles - based on a written claim of their parents or people replacing parents, or of the authorized representatives of the child protection services (in case there are no parents and persons replacing parents) or with their written consent. 
We have already mentioned that the measures of the state protection are organized by the divisions of several law enforcement bodies and other bodies of the state authority, and this unfortunately results in the departmental (unilateral) approach to the complicated complex task. In juridical literature the attention is timely focused on this circumstance. The scientists not that the issues of practising the state protection deal with the spheres of activity of many federal bodies of the executive authority, that is why the full realization of the law in only possible only through the consolidation of the efforts on solving the complex of the protected persons safety problems (Tomilova, N. 2012). In connection with that, N. I. Kryukova proposes to create a unified service that would supervise the protection tasks in all the law enforcement system (Kryukova, N. 2012).

\section{CONCLUSION}

This decision should be well thought-over, the positive and the negative features of the existing regulation should be properly analysed. The consolidation of efforts of the divisions of the number of the power structures is definitely important. We need to aim for that. At the same time, the fragmentation of the system of the state protection bodies allows to quickly react to the threats received. This circumstance needs to be also taken into account.

The list of the existing problems is unfortunately not exhaustive. With this, the conclusion needs to be made that the institution of providing safety for the judges, officials of the law-enforcement and control bodies; participants of the criminal case, their close relatives, relatives and people important for them, - has proved its effectiveness and is successfully used by the courts and the law enforcement bodies.
The scientists and the practicians purposefully study the legislation and the law enforcement practice of the number of countries (the USA, Great Britain, France, Spain, Italy, Germany and other states). This adds to the improvement of the national legislation and the practice of its application. 


\section{REFERENCES}

Ivanov, I.S. Psychological Approach to the Safety of the Persons Protected // Rossiyskiy Sledovatel, 2012, \#19, P.41.

Kryukova, N.I. Problems of Providing Safety for the Witnesses // Rossiyskaya Yustitsiya, 2012, \# 2, P. 43.

Kulikov, V. A Private Prison - not a Luxury. Interview with President of the Federal Chamber of Lawyers Y. Pilipenko // Rossiyskaya Gazeta, 2016, June 12., P. 6.

Ramazanov, I. The Protection of the Witness should be Thought over by all the Participants of the Criminal Court Proceedings. Interview with Head of the Directorate on Provision the Safety of the Persons Subject to the State Protection by the RF MIA, Major-General of Police A.V. Lebedev // Ugolovny Process, 2012, \# 7, P. 35 .

Samoroka V., Beketov, M. Interaction of the Investigators of the Officials of the of the Divisions of the State Protection when Providing Safety of the Participants of the Criminal Court Procedures // Ugolovnoye Pravo, 2012, \#2, P. 102-106.

Timoshenko, A. The Secrecy of Data about the Personalities of the Criminal Court Procedure Participants // Zakonnost, 2011, \# 7, P. 53.

Tomilova, N.S. Principles of the State Protection of the Complainants, Witnesses and Other Participants of the Criminal Court Proceedings: thesis: Candidate of Juridical Sciences. M., 2009. P. 10.

Urukov, V.N. About the Evidentiary Force of the testimonies of the Anonymous Witnesses (with the European Court precedents) // Rossiyskaya Yustitsiya, 2009. \# 2.
Zheltobryukhov, S.P. State Protection of the Complainants and the Witnesses // Rossiyskaya Yustitsiya, 2012, \# 3. P. 54; 